\title{
Deep Planting Long-Stem Nursery Stock: An Innovative Method to Restore Riparian Vegetation in the Arid Southwest
}

\author{
By David R. Dreesen and Gregory A. Fenchel
}

\section{On the Ground}

- The successful establishment of riparian shrubs in the arid Southwest has been accomplished by using "deep planting" methods in riparian areas that lack overbank flooding.

- This methodology involves the immediate exploitation of capillary fringe moisture by the existing root system of long-stem nursery stock and the deep burial of native shrub root crowns.

- The methodology precludes or drastically reduces the need to apply irrigation water in arid and semi-arid environments in order to establish riparian shrubs and trees by deep planting long-stem native nursery stock.

Keywords: capillary fringe, phreatophyte, root crown, watering tube, water table.

Rangelands 36(2):52-56

doi: 10.2111/RANGELANDS-D-13-00065.1

(C) 2014 The Society for Range Management

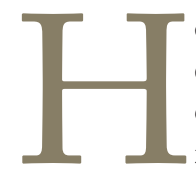

ow does a restoration specialist in the Southwest establish native riparian vegetation when often confronted with two critical site limitations: meager and unpredictable precipitation and the lack of overbank flooding? Revegetation of disturbed riparian sites has been accomplished using novel planting methods and nursery stock where natural regeneration can no longer be expected.

Many riparian plant communities in the Southwest have been altered by human activities. These disturbances include reduction of flood events on major rivers by impounding high flows, levees restricting channel width, straightening and deepening channels to improve water conveyance, installation of drain channels to develop arable land by lowering water tables, and introduction of noxious woody species that have invaded vast areas of riparian habitat.

Properly functioning riparian areas provide many ecological services including recreation, fish and wildlife habitat, dissipation of flood flows, and water quality protection. The rehabilitation of disturbed riparian areas has been deemed a high priority societal goal as evidenced by the amount of funding spent on both private and public lands to restore native riparian plant communities in the past several decades.

\section{Restoring Riparian Vegetation in the Southwest}

Many common overstory trees and understory shrubs in riparian areas are phreatophytes. Phreatophytes have been described as plants whose "roots are in the water table or its capillary fringe during all or most of the growing season."1 The capillary fringe has been described as "the zone immediately above the water table" where the water is held "by interfacial forces (surface tension)" and "is typically saturated to some distance above its base at the water table." Thus, the capillary fringe serves as a constant water supply with sufficient aeration for roots of phreatophytic species to flourish. In dry climates, the natural regeneration of riparian species is dependent on overbank flooding, but the persistence of this vegetation is dependent on the appropriate ground water level ${ }^{3}$ and associated capillary fringe.

On lower elevation floodplain sites in the Southwest, cottonwoods, Rio Grande (Populus deltoides Bartram ex Marsh. subsp. wislizeni [S. Watson] Eckenwalder), plains (Populus deltoides Bartram ex Marsh. subsp. monilifera [Aiton] 
Eckenwalder), Fremont (Populus fremontii S. Watson) and Goodding's willow (Salix gooddingii C.R. Ball) are common obligate riparian overstory species and phreatophytes. An assortment of common understory shrubs on these sites in New Mexico are also obligate riparian species including desert false indigo (Amorpha fruticosa L.), screwbean mesquite (Prosopis pubescens Benth.), Baccharis L. species, New Mexico olive (Forestiera pubescens Nutt. var. pubescens), Torrey wolfberry (Lycium torreyi A. Gray), and coyote willow (Salix exigua Nutt.). ${ }^{1}$ Restoration with appropriate native species is being attempted where natural regeneration can no longer be relied upon because overbank flooding has been perturbed or where exotic saltcedar (Tamarix ramosissima Ledeb.) and Russian olive (Elaeagnus angustifolia L.) have been removed.

Any nursery stock plantings must exploit the capillary fringe as rapidly as possible. If conventional transplants with shallow root systems are planted with root crowns at the soil surface, substantial precipitation or flood events must occur to provide sufficient deep soil moisture for roots to extend to the capillary fringe. Although this strategy is effective in mesic environments with high annual precipitation and frequent high water events, it is doomed to failure in arid and semiarid regions where low annual precipitation and infrequent overbank flood events prevent roots from reaching the capillary fringe. One option is frequent irrigation, but this can be impractical because:

1) Surface application of water in basins encourages annual weed competition and typically does not apply sufficient water to moisten the soil profile down to the capillary fringe;

2) Restrictive soil layers can prevent roots from reaching the unsaturated zone above the water table;

3) Small transplants are difficult to locate in an expansive out-planting area to repeatedly apply water; and

4) Frequent watering of numerous and widely dispersed plants requires a substantial long-term commitment of labor and equipment.

Therefore, we have developed a specialized nursery stock type and out-planting method that requires little if any irrigation to achieve the goal of large-scale revegetation of disturbed or decadent riparian areas. The approach the Los Lunas Plant Materials Center (LLPMC) has been investigating is "deep planting," which involves placing the existing root system of a transplant or the potential root system of a cutting into the capillary fringe. Instead of using "tallpots" with long root systems, we developed a new long-stemmed nursery stock type that can be deep planted so its roots are in contact with the capillary fringe. Publications summarizing the refinement of these deep-planting techniques can be found at the website of the USDA-NRCS Los Lunas Plant Materials Center, New Mexico. ${ }^{4}$

For deep planting of rooted nursery stock to be successful, the plants must tolerate burial of the root crown. Natu- rally regenerated riparian plant communities are adapted to burial by sediments. For example, Gonzalez ${ }^{5}$ reported longterm burial and survival of plains cottonwoods over 100 years old with root crowns buried by at least $1 \mathrm{~m}$ (3.3 feet) of alluvium and adventitious roots growing out of these buried trunks.

\section{Tallpots-Precursor to Long-Stemmed Container Nursery Stock}

The establishment of important woody riparian species other than cottonwoods and willows, particularly understory shrubs, has not been generally successful using shoot cuttings. As a result, about 10 years ago, we began producing riparian understory transplants in 76- $\mathrm{cm}$ (30-inch) long and 10- $\mathrm{cm}$ (4inch) diameter "tallpots" constructed from PVC drain pipe ${ }^{6}$ as a means to allow rapid root access to the capillary fringe and minimize irrigation requirements (see Fig. 1). An embedded PVC watering tube $(2.5-\mathrm{cm}$ [1-inch] diameter with

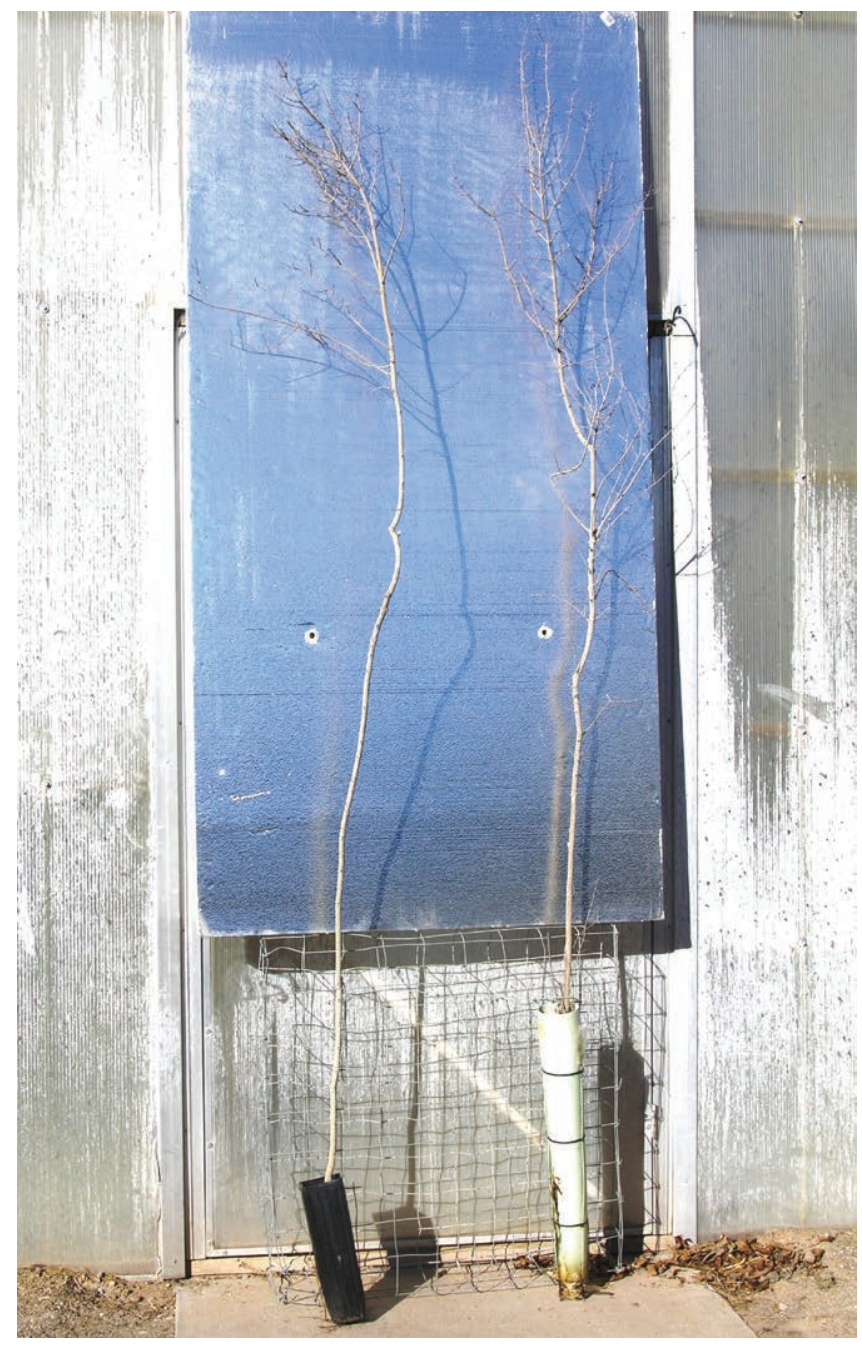

Figure 1. Dormant long-stem New Mexico olive in a $10 \times 10 \times 36 \mathrm{~cm}$ (4× 4× 14 inch) 1-gallon treepot (left) and a 76-cm (30-inch) long and 10-cm (4-inch) diameter tallpot (right). Total transplant height (pot plus stem) approximately $3.3 \mathrm{~m}$ (11 feet). 


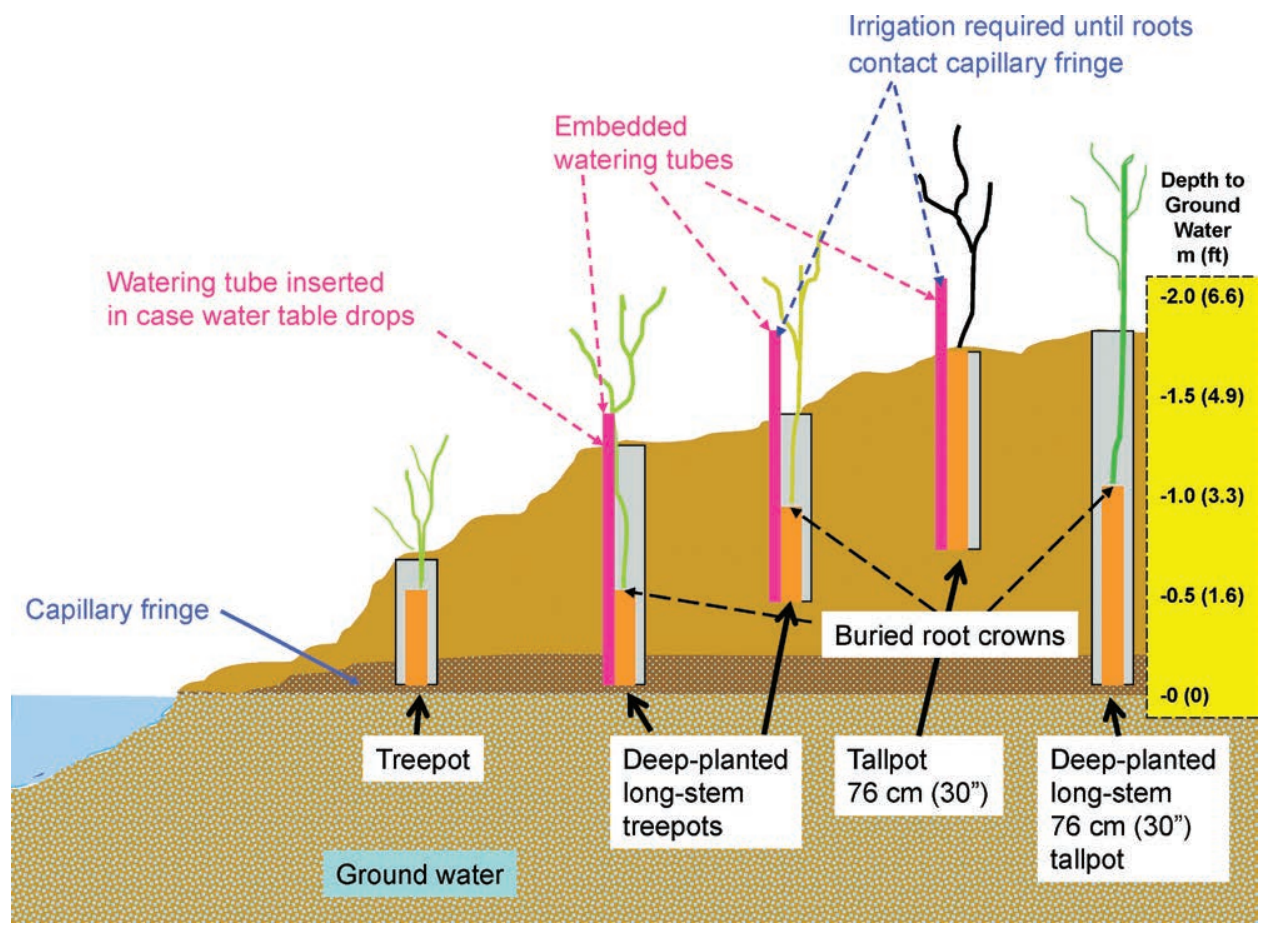

Figure 2. Planting scenarios for treepot and tallpot stock depending on the depth to the capillary fringe. If the root balls are not in contact with the capillary fringe, irrigation through the embedded watering tubes will be required until the roots can access ground water. If the water table declines during severe droughts, several applications of water into watering tubes will enhance survival.

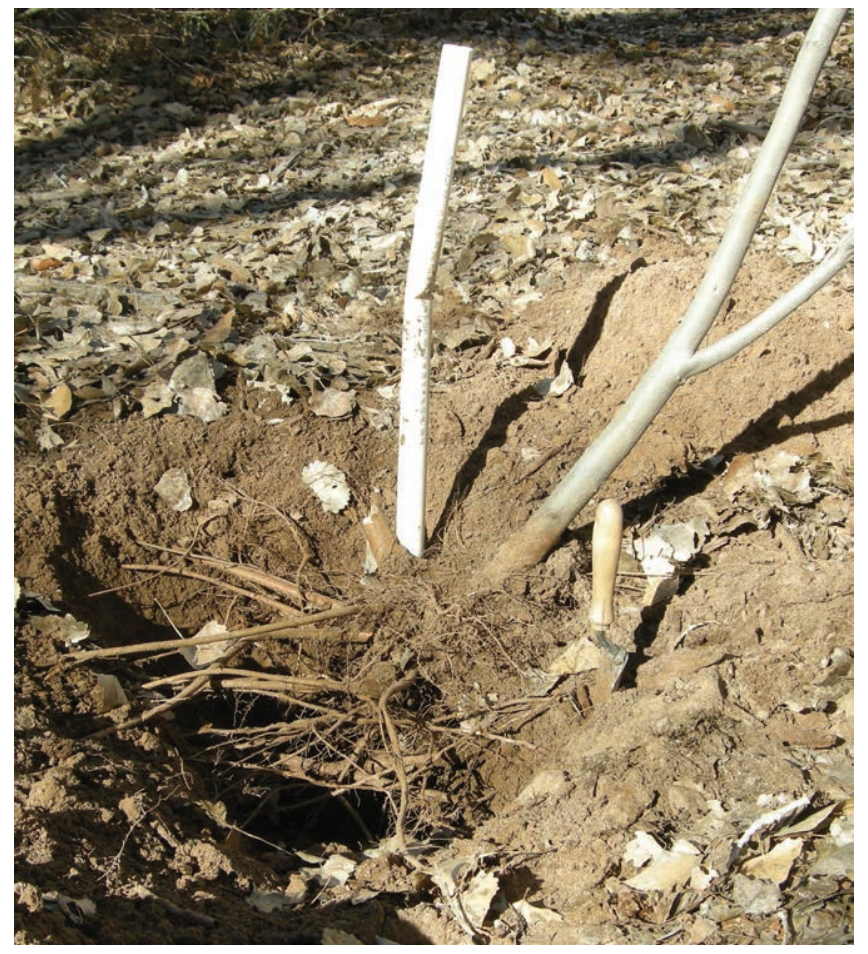

Figure 3. Adventitious root development on the buried stem of a desert false indigo (Amorpha fruticosa L.) long-stem treepot stock after eight growing seasons. Note embedded 1-inch PVC watering tube. This planting re-introduced native understory shrubs following saltcedar removal along the Rio Grande near Belen, New Mexico. perforations in the bottom third) was placed in the planting hole if the depth to the capillary fringe was greater than the length of the tallpot root system. A few irrigations using the watering tube provided deep soil moisture for rapid root extension into the capillary fringe (the watering tube technique is similar to the deep pipe irrigation of Bainbridge). ${ }^{7}$ See Figure 2 for a variety of watering tube applications. If extreme conditions such as drought or a declining water table were encountered, a maximum of three irrigations per year were applied for the first two years using the watering tubes. Success rates of $90 \%$ or more were achieved in many situations.

Some challenging riparian sites had low or declining water tables where the bottom of a $71-\mathrm{cm}$ (28-inch) root ball was a considerable distance above the capillary fringe. On these sites, we tried "long-stem" plants grown in tallpots with stem heights of up to $2 \mathrm{~m}$ (6 feet) and total plant heights of up to $2.8 \mathrm{~m}$ (9 feet). When the root crowns of these "long-stem" plants were buried at depths of up to $1 \mathrm{~m}$ ( 3 feet) in holes up to $2 \mathrm{~m}$ (6 feet) deep, we had good survival. This approach violates several basic horticultural tenets that consider the deep burial of the root crown and transplants with large shoot-toroot ratios as detrimental practices.

Our first trials with deep planting of long-stemmed nursery stock included New Mexico olive, desert false indigo, and Emory's baccharis (Baccharis emoryi A. Gray). Some of these plants were excavated after one or two growing seasons and adventitious roots had developed along the stem in the upper $0.3 \mathrm{~m}$ ( 1 foot) of the soil profile and impressive shoot growth 
indicated the extension of roots into the capillary fringe (see Fig. 3).

\section{Development of Long-Stem Nursery Stock in Treepots}

As it became apparent that deep planting of long-stem stock might hold promise for improved establishment on sites with deeper water tables, the LLPMC tested the same procedure with long-stem stock grown in $10 \times 10 \times 36 \mathrm{~cm}(4 \times 4 \times 14$ inch) 1-gallon treepots (Tall One Treepot; Stuewe and Sons, Inc., Tangent, OR) as shown in Figure 1. The time, expense, and inconvenience of producing $76-\mathrm{cm}$ (30-inch) tallpots are good reasons for testing 1-gallon treepots. Long-stem treepots of the three species mentioned above were installed in comparison plantings along with deep-planted, tallpot stock; similar survival rates, growth rates, and adventitious root development were observed for both stock types. Planting schemes that are dependent on the depth to the capillary fringe are illustrated in Figure 3 for both treepot and tallpot stock. Advantages of growing 1-gallon, long-stem treepot stock include ease of transplanting seedlings into the container, ease of watering and moving plants, and the simplicity of supporting and insulating treepots in the nursery. These efficiencies result in a production cost reduction of long-stem treepots by at least $50 \%$ relative to tallpot stock.

Other species of the cottonwood floodplain forests that have been found to thrive when deep planted as long-stem stock include:

- golden currant (Ribes aureum Pursh)

- screwbean mesquite

- skunkbush sumac (Rhus trilobata Nutt.)

- netleaf hackberry (Celtis laevigata Willd. var. reticulata [Torr.] L.D. Benson)

- silver buffaloberry (Shepherdia argentea [Pursh] Nutt.)

- boxelder (Acer negundo L.)

Some understory riparian species are not as amenable to this technique because of the difficulty in growing stock with long stems in containers. Torrey's wolfberry and four-wing saltbush (Atriplex canescens [Pursh] Nutt.) are two prime examples that require extensive pruning and tying the primary shoot to a stake to develop sufficient vertical growth to be used for long-stem planting.

After our initial long-stem deep burial trials were installed, we became aware of some revegetation projects in Australia that utilized a similar planting method. The originator calls the approach "long-stem tubestock" and acknowledges that this methodology runs counter to conventional horticultural recommendations regarding deep burial of root crowns and use of plants with long stems in small containers. ${ }^{8}$ This technique employs small container sizes, $5 \times 10 \mathrm{~cm}$ $(2 \times 5$ inch $)$, and attempts to produce stock with stem heights of 0.9 to $1.2 \mathrm{~m}$ (3 to 4 feet). Much of the Australian longstem tubestock planting has been in riparian environments,

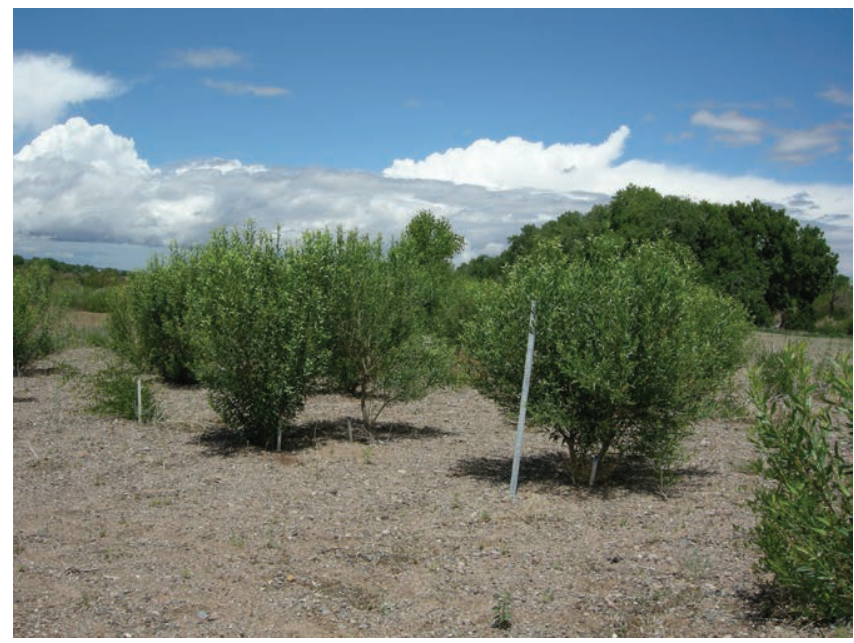

Figure 4. Emory's baccharis (Baccharis emoryi A. Gray) long-stem planting near Bernalillo, New Mexico. Long-stem 1-gallon treepots were planted in December 2006; photograph was taken in June 2009. Note 150-cm (5-foot) ruler and embedded 1-inch PVC watering tubes.

but this stock type has also been used for arid region plantings in areas with highly saline surface soils as well as sand dune revegetation.

\section{Conclusion}

The concept of deep planting long-stemmed nursery plants is based on the phreatophytic nature of most riparian plant species. Given the phreatophytic requirement for root proliferation in the capillary fringe, any means feasible to expedite this root development should be a worthwhile expenditure of resources. By deep planting, transplants make an immediate hydrologic connection to the capillary fringe, which supports rapid establishment and growth. This approach is a departure from established horticultural practices concerning the burial of root crowns and the use of planting stock with large shootto-root ratios. The adaptation of riparian species to burial by sediment in fluvial systems makes this a viable method of minimizing irrigation requirements for establishment. We have observed $90 \%$ plus survival rates with minimal postplanting care if high-quality, long-stem nursery stock is deep planted on appropriate sites (see Fig. 4). The deep planting of long-stem stock can preclude or drastically reduce the need to apply irrigation water to establish many of the dominant riparian shrub and tree species of the Southwest. The cost savings of minimal or no watering and high transplant success will, in most situations, far outweigh the added expense of the planting stock and augering planting holes into the capillary fringe.

\section{References}

1. Dick-Peddie, W. A. 1993. New Mexico vegetation, past, present, and future. Albuquerque, NM, USA: University of New Mexico Press. 244 p.

2. Lohman, S. W., R. R. Bennett, R. H. Brown, H. H. Cooper, Jr., W. J. Drescher, J. G. Ferris, A. I. Johnson, C. L. 
McGuinness, A. M. Piper, M. I. Rorabaugh, R. W. StallMAN, AND C. V. Theis. 1972. Definitions of selected groundwater terms-revisions and conceptual refinements. Geological Survey Water-Supply Paper 1988. Washington, DC, USA: US Government Printing Office. 21 p.

3. Hupp, C. R., and W. R. Osterkamp. 1996. Riparian vegetation and fluvial geomorphic processes. Geomorphology 14:277-295.

4. USDA-NRCS. 2008a. Los Lunas Plant Materials Center Publications-Brochures. Albuquerque, NM, USA: USDA Natural Resources Conservation Service New Mexico. Available at: http://www.nrcs.usda.gov/wps/portal/nrcs/detail/nm/ plantsanimals/?cid=nrcs144p2_068887. Accessed 15 October 2012.

5. Gonzalez, M. A. 2001. Recent formation of arroyos in the Little Missouri Badlands of southwestern North Dakota. Geomorphology 38:63-84.

6. USDA-NRCS. 2008b. Plant Technology Fact Sheet: Tall-Pots. Albuquerque, NM, USA: USDA-NRCS Los Lunas Plant Ma- terials Center. Available at: http://www.nrcs.usda.gov/Internet/ FSE_DOCUMENTS/nrcs144p2_066041.pdf. Accessed 15 October 2012.

7. Bainbridge, D. A. 2007. A guide for desert and dryland restoration: New hope for arid lands. Washington, DC, USA: Island Press. 391 p.

8. Hicks, B. 2003. A solution to the willow problem, long-stem tube-stock. Australian Plants Online. March 2003. Association of Societies for Growing Australian Plants. Available at: http:// asgap.org.au/APOL29/mar03-6.html. Accessed 21 January 2014.

Authors are Agronomist/Horticulturist, Los Lunas Plant Materials Center, USDA-NRCS, Los Lunas, NM 87031, USA, David. Dreesen@nm.usda.gov (Dreesen) and Manager, Los Lunas Plant Materials Center, USDA-NRCS, Los Lunas, NM 87031, USA (Fenchel). 